\title{
Supply chain collaboration in industrial symbiosis networks
}

\author{
Herczeg, Gabor; Akkerman, Renzo; Hauschild, Michael Zwicky
}

Published in:

Journal of Cleaner Production

Link to article, DOI:

10.1016/j.jclepro.2017.10.046

Publication date:

2018

Document Version

Peer reviewed version

Link back to DTU Orbit

Citation (APA):

Herczeg, G., Akkerman, R., \& Hauschild, M. Z. (2018). Supply chain collaboration in industrial symbiosis networks. Journal of Cleaner Production, 171, 1058-1067. https://doi.org/10.1016/j.jclepro.2017.10.046

\section{General rights}

Copyright and moral rights for the publications made accessible in the public portal are retained by the authors and/or other copyright owners and it is a condition of accessing publications that users recognise and abide by the legal requirements associated with these rights.

- Users may download and print one copy of any publication from the public portal for the purpose of private study or research.

- You may not further distribute the material or use it for any profit-making activity or commercial gain

- You may freely distribute the URL identifying the publication in the public portal

If you believe that this document breaches copyright please contact us providing details, and we will remove access to the work immediately and investigate your claim. 


\section{Accepted Manuscript}

Supply chain collaboration in industrial symbiosis networks

Gábor Herczeg, Renzo Akkerman, Michael Zwicky Hauschild

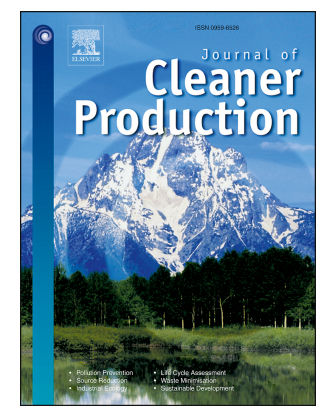

PII:

S0959-6526(17)32338-7

DOI:

10.1016/j.jclepro.2017.10.046

Reference:

JCLP 10838

To appear in: Journal of Cleaner Production

Received Date: 29 May 2017

Revised Date: 3 October 2017

Accepted Date: 6 October 2017

Please cite this article as: Herczeg Gá, Akkerman R, Hauschild MZ, Supply chain collaboration in industrial symbiosis networks, Journal of Cleaner Production (2017), doi: 10.1016/j.jclepro.2017.10.046.

This is a PDF file of an unedited manuscript that has been accepted for publication. As a service to our customers we are providing this early version of the manuscript. The manuscript will undergo copyediting, typesetting, and review of the resulting proof before it is published in its final form. Please note that during the production process errors may be discovered which could affect the content, and all legal disclaimers that apply to the journal pertain. 


\title{
Supply chain collaboration in industrial symbiosis networks
}

\author{
Gábor Herczega,b, Renzo Akkerman $^{\mathrm{c}, *}$, Michael Zwicky Hauschild ${ }^{\mathrm{a}}$ \\ ${ }^{a}$ Technical University of Denmark, Department of Management Engineering, Kgs. Lyngby (Copenhagen), Denmark \\ ${ }^{b}$ Technical University of Munich, TUM School of Management, Munich, Germany \\ ${ }^{c}$ Wageningen University, Operations Research and Logistics group, Wageningen, The Netherlands
}

\begin{abstract}
A strategy supporting the development towards a circular economy is industrial symbiosis (IS). It is a form of collaborative supply chain management aiming to make industry more sustainable and achieve collective benefits based on utilization of waste, by-products, and excess utilities between economically independent industries. Based on an extensive analysis of published studies on existing IS collaborations and interviews with central stakeholders of a comprehensive IS, this paper investigates IS from a supply chain collaboration perspective. A theoretical framework is built and used to discuss how industrial symbiosis pursues sustainability and to identify the main collaboration aspects and performance impacts. This framework is then used in the analysis of selected published cases. Based on this, we derive propositions on the organizational and operational requirements for collaboration in the context of IS networks, related to the supply chain integration and coordination practices. As IS has only received little attention in the operations and supply chain management community, our propositions directly lead to future research directions. Furthermore, the analysis in this paper provides directions to increase the feasibility and resource efficiency of IS networks and can hence be used by stakeholders involved in these networks.
\end{abstract}

Keywords: sustainability, circular economy, industrial symbiosis, resource efficiency, supply chain, collaboration

Paper type: Original article

\footnotetext{
*Corresponding author: Renzo Akkerman, Wageningen University, Operations Research and Logistics Group, Hollandseweg 1, 6706 KN Wageningen, The Netherlands.

Email address: renzo. akkerman@wur.nl (Renzo Akkerman)
} 


\section{Introduction}

Industrial symbiosis (IS) is a concept based on the idea of industrial ecosystems, establishing symbiotic relationships between economically independent industries, typically in a relatively close geographical proximity (Chertow, 2000). An industrial ecosystem refers to the idea of reusing waste from one industrial process in another industrial process. In this way, the consumption of materials and energy is optimized, and by-products from one industry serve as raw materials for other industries, reducing disposal of waste and loss of resources (Frosch and Gallopoulos, 1989).

IS aims to achieve benefits in different dimensions. Economically, companies benefit by access to cheaper sourcing, avoiding disposal costs, and/or gaining extra profit from selling the by-products. Overall, IS increases resource efficiency by producing more outputs from the same amount of raw materials. Environmentally, the benefits are reduced natural resource consumption and waste disposal and reduction of emissions to air, water, and soil from the production of the saved raw materials (e.g. Schwarz and Steininger, 1997; Chertow and Lombardi, 2005; Jacobsen, 2006). Finally, from a social perspective, IS emphasizes the local community, and working cooperatively with other industries and governmental bodies to contribute to regional economic development (Baas and Boons, 2004)). As such, the ideas behind IS extend into all three dimensions of sustainability, summarize in the triple bottom line, covering profit, planet, and people. In its Action Plan for Circular Economy, the European Commission targets a more sustainable and resource-efficient economy in Europe and identifies the need to promote IS and announces revised European regulation of waste in order "to clarify rules on by-products to facilitate industrial symbiosis and help create a level playing field across the EU" (EC, 2015).

From an operations and supply chain management perspective, IS introduces new supplierbuyer relationships and forms a collaborative supply chain network between previously unrelated companies (Bansal and McKnight, 2009; Miemczyk et al., 2012). As such, IS expands the existing basis of supply chain partnerships. However, IS relations are different from traditional supply

chain relations, because the traded by-products are typically outside of the core business of the 
supplier. This requires some degree of shared strategic visions and collective decision-making, necessitating mutual recognition, trust, and information sharing, and often some sort of central organization (Lowe, 1997; Baas and Boons, 2004; Chertow, 2007). Also, newly introduced interdependencies often imply technical challenges relating to the quantity and quality of waste flows (Bansal and McKnight, 2009). Furthermore, the success of IS networks can be undermined by the lack of economic incentives and by technological developments that change the balance in the industrial ecosystem (Mirata, 2004). However, IS development is an evolutionary process that goes through structural and cultural embeddedness and institutionalization, which takes time and social capabilities (Chertow and Ehrenfeld, 2012).

Despite plentiful examples of IS networks, seemingly containing numerous operations and supply chain management challenges, the IS phenomenon has not received much attention in the operations and supply chain management literature, even though Kleindorfer et al. (2005) recognized the importance of building bridges between sustainable operations management and industrial ecology.

In this paper, we aim to improve the understanding of supply chain collaboration in IS networks by combining relevant theoretical perspectives with an empirical perspective based on a collection of published IS case studies. We first develop a theoretical framework that views sustainability performance through profit, planet, and people and the effects of stakeholders and collaborative supply networks. Combined with the empirical base of IS case studies, this leads to the development of propositions regarding the main organisational and operational challenges in IS networks. With the identification of these challenges, we improve the understanding of key features of supply chain collaboration in IS networks, and develop a theoretical foundation for the successful organization and operation of IS networks.

We postulate that the improved understanding of the supply chain collaboration challenges in IS networks will $(i)$ be highly beneficial in understanding the sustainable performance of IS networks, (ii) provide directions to increase the feasibility and resource efficiency of IS networks, 
and (iii) provide research directions for supply chain management researchers interested in socially and environmentally responsible operations.

The remainder of this paper is structured as follows. In Section 2, we develop a theoretical framework that links IS to sustainable operations management and supply network collaboration. Then, in Section 3, we describe our empirical base of IS case studies and analyze the IS phenomenon as a practice of sustainable operations management, discussing its stakeholders, drivers, and performance. In Section 4, we subsequently identify organizational and operational challenges with respect to supply chain collaboration, and formulate our propositions on the integration and coordination practices in IS networks. Finally, in Section 5, we conclude our paper, reflect on successful supply chain collaboration practices in IS networks, and discuss further research opportunities.

\section{Related literature and theoretical framework}

There are several related streams of literature. First, the industrial ecology literature in which the concept of IS originated. Major contributions are cited throughout this paper. Secondly, as IS represents collaborative efforts to increase sustainability, two streams of research within operations and supply chain management are relevant: sustainable operations management and supply network collaboration. In the following, a theoretical framework is developed based on these two streams.

\subsection{Sustainable operations management}

Following Kleindorfer et al. (2005), sustainable operations management can be understood as a collection of practices that integrate a company's profit- and efficiency-related objectives with broader (social) considerations of internal and external stakeholders and the impact on the natural environment. This does not necessarily cover sustainability in the literal sense of the word, but ideally, this eventually aims to increase the overall sustainability of the production operations (see also Hauschild, 2015). 
Many stakeholders play a role in sustainable operations management, some more focused on environmental performance, others more focused on social performance (Meixell and Luoma, 2016). Organizational stakeholders include the supply network itself, i.e. upstream and downstream business partners, consumers, and employees (Linton et al., 2007). In addition, there are external stakeholders, i.e. governments, regulatory bodies, and trade associations, community stakeholders such as environmental organizations, media outlets, and people that live in geographical proximity of the IS network (Henriques and Sadorsky, 1999). In general, these stakeholders lead to incentives towards sustainability (Seuring and Müller, 2008). We build on the generally accepted view on sustainability according to which incentives and drivers behind sustainability boil down to profit-, planet-, and people-related issues and performance expectations, influencing a company's operations strategy (e.g. Linton et al., 2007; Carter and Rogers, 2008; Diabat and Govindan, 2011; Tang and Zhou, 2012)

\subsection{Supply network collaboration}

Companies collaborate by working towards mutual goals, developing processes or products jointly, sharing the cost of investments, mitigating risk, or sharing information (Kumar and van Dissel, 1996; de Leeuw and Fransoo, 2009).

We distinguish between organizational and operational aspects that relate to the development and organization of relationships and to the functioning of material exchanges, respectively. In addition, we distinguish between supply chain integration and coordination as collaborative practices. In general, integration covers strategic developments and the flow of goods (Frohlich and Westbrook, 2001; Vachon and Klassen, 2007), whereas coordination covers the management and control of the resulting dependencies (Arshinder and Deshmukh, 2008). In other words, integration builds links between companies, whereas coordination aims to enable partners to work together effectively and efficiently (see also Figure 1).

From an organizational perspective, strategic integration defines interdependencies in a supply network. Integration usually entails a communication setting to transfer and integrate knowledge 


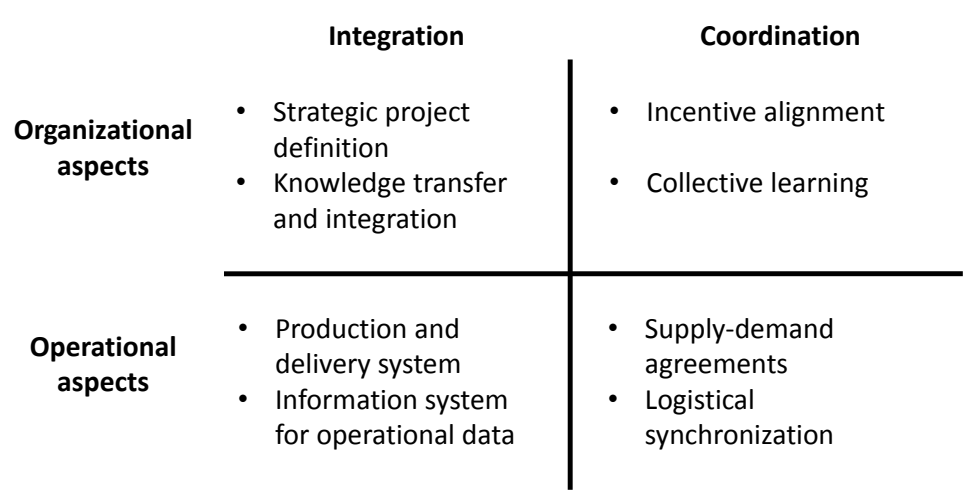

Figure 1: Overview of organizational and operational aspects of coordination and integration in collaborative supply networks.

and expertise, and often results in particular collaborative strategic projects such as infrastructural development, product design, or process design (Vachon and Klassen, 2007). Knowledge transfer manifests itself through changes in knowledge and performance of the recipient company (Inkpen and Tsang, 2005). In a collaborative supply network, knowledge and experience sharing contributes to the development of mutual understanding of circumstances that affect companies, and help develop core capabilities to address common challenges. The coordination of this "collective learning" entails analyzing circumstances and synthesizing improvements, and engaging key stakeholders in collaboration (Simatupang et al., 2002). Furthermore, to make collaboration sustainable, companies have to coordinate the distribution of risks and benefits (Kumar and van Dissel, 1996). To align incentives, companies share objectives, make joint decisions, and often rely on each other's trustworthiness (Hoyt and Huq, 2000; de Leeuw and Fransoo, 2009).

From an operational perspective, integration defines a production and delivery system. Consequently, logistical integration is characterized by exchanging explicit information between companies, such as production plans and inventory levels, which implies better visibility of each other's tactical plans (Frohlich and Westbrook, 2001; Vachon and Klassen, 2007). Typically, logistical integration requires an information system that collects, stores, and works with operational data. The coordination of logistics (synchronization) entails a mediation function aiming to match products with customer demand while lowering costs and minimizing uncertainties (Simatupang et al., 


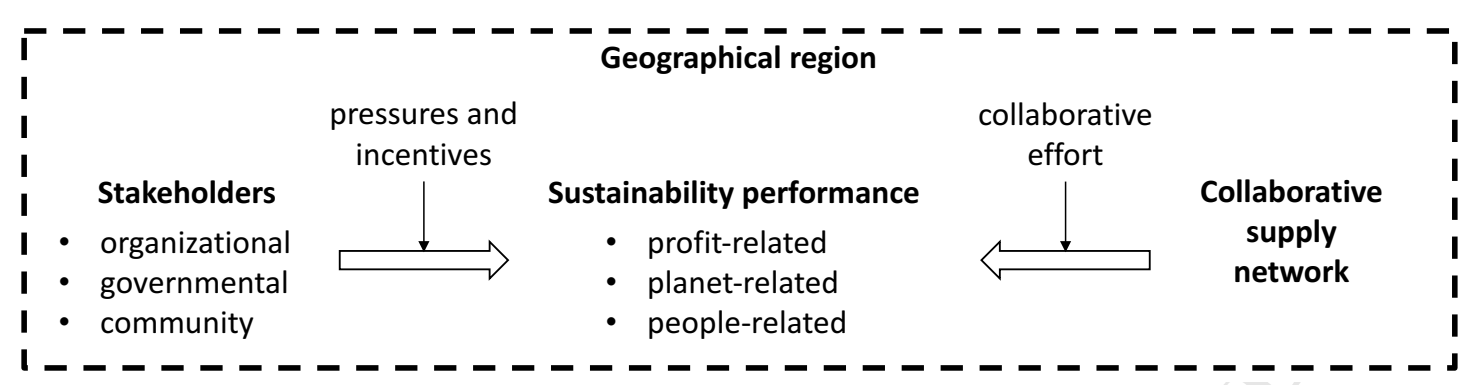

Figure 2: Theoretical framework to analyze the sustainability of industrial symbiosis networks.

2002). Furthermore, to coordinate the terms of production and delivery and minimize risks, suppliers and customers typically make contracts and agreements (Jagdev and Thoben, 2001).

Although collaboration emphasizes joint efforts and collective benefits, companies do not always share these equally, potentially leading to conflicts. Moreover, companies don't necessarily depend on each other to the same extent, leading to asymmetrical relationships. Because of low benefits and/or high risks, companies may not participate or exit the network. The growing importance of sustainable supply chains makes it increasingly challenging to ignore collaboration across industries (Spekman and Davis, 2016).

\subsection{Theoretical framework}

Figure 2 structures the concepts we discussed, presenting the theoretical framework we use to analyze IS networks from an operations and supply chain management perspective. The framework considers stakeholders as well as collaborative supply network practices with the goal of improving sustainability performance within a geographical region. In the following, we discuss the different stakeholders, and how their drivers, expectations, and management practices target the triple bottom line. Subsequently, we focus on collaborative efforts in IS and analyze operational and organizational aspects based on integration and coordination. 


\section{Industrial symbiosis - stakeholders, drivers, and performance}

In the literature, IS networks are also referred to as industrial recycling networks, regional synergies, and eco-industrial parks (Lowe, 1997; Schwarz and Steininger, 1997; Chertow, 2007; Geng and Côté, 2002; Massard et al., 2012). Over the years, many such initiatives have been launched, of which the Kalundborg IS in Denmark is probably the world's best-known example (Chertow, 2000; Jacobsen, 2006). It is often also considered the archetypical IS network and is the textbook example used as inspiration for other initiatives.

\subsection{Empirical data on industrial symbiosis practices}

In order to provide an empirical basis to derive the general characteristics of IS, we expand the perspective beyond the Kalundborg example and rely on a collection of fifteen IS networks from around the world identified in the literature (see Table 1). The collection stems mainly from the literature on industrial ecology and environmental engineering and only uses networks that have detailed case descriptions. The purpose of this collection is not to present an exhaustive list of IS networks. Our literature-based data has been supplemented by a series of in-depth interviews with stakeholders of the Kalundborg IS network including some of the participating companies and the organizational unit.

\subsection{Geographical characteristics}

IS can manifest over different geographical distances from co-localization in industrial parks to larger regional developments (Chertow, 2000). Industrial parks, for example in Kwinana, Australia, and Ulsan, South Korea, can turn into eco-industrial parks implementing IS between already co-located industries (van Beers et al., 2007; Behera et al., 2012). Similarly, IS was developed in Kansas by engaging local production companies (Cimren et al., 2011). In Germany, several industrial areas in the Rhine-Neckar region are connected through waste exchanges leading to a more dispersed regional IS (Sterr and Ott, 2004). 
Table 1: List of industrial symbiosis networks

\begin{tabular}{|c|c|c|c|c|c|}
\hline Industrial symbiosis & $\begin{array}{l}\text { No. of } \\
\text { compa- } \\
\text { nies }\end{array}$ & $\begin{array}{l}\text { Exchange } \\
\text { types }^{a}\end{array}$ & $\begin{array}{l}\text { Develop- } \\
\text { ment } \\
\text { types }^{b}\end{array}$ & $\begin{array}{l}\text { Organizational } \\
\text { unit }\end{array}$ & $\begin{array}{l}\text { Main reference } \\
\text { in literature }\end{array}$ \\
\hline $\begin{array}{l}\text { Chamusca, Portugal } \\
\text { (Relvao Eco Ind. } \\
\text { Park) }\end{array}$ & 15 & B & $\mathrm{D}$ & $\begin{array}{l}\text { Chamusca } \mathrm{Mu}- \\
\text { nicipality }\end{array}$ & $\begin{array}{l}\text { Costa and } \\
\text { Ferrão (2010) }\end{array}$ \\
\hline $\begin{array}{l}\text { Eno, Finland (Uima- } \\
\text { harju Industrial Park) }\end{array}$ & 6 & $\mathrm{~B} ; \mathrm{U}$ & $S$ & no & Saikku (2006) \\
\hline $\begin{array}{l}\text { Guayama, } \\
\text { Rico, USA }\end{array}$ & 3 & $\mathrm{U}$ & $S$ & $\begin{array}{l}\text { Wastewater Ad- } \\
\text { visory Council }\end{array}$ & $\begin{array}{l}\text { Chertow and } \\
\text { Lombardi } \\
\text { (2005) }\end{array}$ \\
\hline $\begin{array}{l}\text { Humber region, } \\
\text { United Kingdom }\end{array}$ & 9 & B; S & $\mathrm{D}$ & $\begin{array}{l}\text { National Indus- } \\
\text { trial Symbiosis } \\
\text { Programme }\end{array}$ & Mirata (2004) \\
\hline Kalundborg, Denmark & 11 & B; U; S & $S$ & $\begin{array}{l}\text { Environmental } \\
\text { Club; Symbio- } \\
\text { sis Institute }\end{array}$ & Jacobsen (2006) \\
\hline $\begin{array}{l}\text { Kansas City, Missouri, } \\
\text { USA }\end{array}$ & 6 & B & $\mathrm{D}$ & yes (name n.a.) & $\begin{array}{l}\text { Cimren et al. } \\
\text { (2011) }\end{array}$ \\
\hline $\begin{array}{l}\text { Kwinana, Western } \\
\text { Australia }\end{array}$ & 15 & $\mathrm{~B} ; \mathrm{U}$ & $\mathrm{D}$ & $\begin{array}{l}\text { Kwinana Indus- } \\
\text { tries Council }\end{array}$ & $\begin{array}{l}\text { van Beers et al. } \\
(2007)\end{array}$ \\
\hline $\begin{array}{l}\text { Nanjangud, South In- } \\
\text { dia }\end{array}$ & 14 & $\mathrm{~B} ; \mathrm{S}$ & $\mathrm{S}$ & no & $\begin{array}{l}\text { Bain et al. } \\
(2010)\end{array}$ \\
\hline $\begin{array}{l}\text { Norrkoping, Sweden } \\
\text { (Handelo bioenergy } \\
\text { complex) }\end{array}$ & 4 & $\mathrm{~B} ; \mathrm{U}$ & D & yes (name n.a.) & $\begin{array}{l}\text { Martin and Ek- } \\
\text { lund (2011) }\end{array}$ \\
\hline $\begin{array}{l}\text { Nova Scotia, Canada } \\
\text { (Burnside Ind. Park) }\end{array}$ & $\mathrm{n} / \mathrm{a}$ & B; S & $S$ & no & $\begin{array}{l}\text { Geng and Côté } \\
(2002)\end{array}$ \\
\hline $\begin{array}{l}\text { Rotterdam, } \\
\text { Netherlands }\end{array}$ & $\mathrm{n} / \mathrm{a}$ & $\mathrm{B} ; \mathrm{U}$ & $\mathrm{D}$ & Deltalinqs & Baas (2011) \\
\hline $\begin{array}{l}\text { Schkopau, Germany } \\
\text { (Valuepark Schkopau) }\end{array}$ & 14 & B; S & $\mathrm{D}$ & no & $\begin{array}{l}\text { Liwarska- } \\
\text { Bizukojc et al. } \\
\text { (2009) }\end{array}$ \\
\hline Styria, Austria & 37 & B & $S$ & $\begin{array}{l}\text { Karl-Franzens- } \\
\text { Uni. Graz } \\
\text { Partnership }\end{array}$ & $\begin{array}{l}\text { Schwarz and } \\
\text { Steininger } \\
(1997)\end{array}$ \\
\hline Tianjin, China & 35 & B & $\mathrm{D}$ & $\begin{array}{l}\text { TEDA Ad- } \\
\text { ministrative } \\
\text { Commission }\end{array}$ & Shi et al. (2010) \\
\hline Ulsan, South Korea & 36 & $\mathrm{~B} ; \mathrm{U}$ & $\mathrm{D}$ & $\begin{array}{l}\text { Korea Indus- } \\
\text { trial Complex } \\
\text { Corporation }\end{array}$ & $\begin{array}{l}\text { Behera et al. } \\
(2012)\end{array}$ \\
\hline
\end{tabular}

${ }^{a}$ Exchange types: B - by-products, $\mathrm{U}$ - utilities, $\mathrm{S}$ - services; ${ }^{b}$ Development types: $\mathrm{S}$ - Spontaneous, D - Designed 
In some cases, there has been a significant top-down effort in designing or creating ISs by transforming existing industrial parks or implementing IS relationships within geographical regions. The National Eco-Industrial Park Development Program in Korea, and the National Industrial Symbiosis Programme (NISP) in the UK are examples (Mirata, 2004; Park et al., 2016). In other cases, IS developed spontaneously as a bottom-up process. In Kalundborg, companies have co-located production plants over the last forty years. The IS network in Eno, Finland, has an even longer history of engaging (forestry) companies in waste exchange for almost sixty years (Saikku, 2006). According to Boons and Janssen (2004), the use of symbiotic relationships was also more common in the nineteenth century when supply chains were more local. The globalization of supply chains reduced such interactions within local communities. An increased focus on sustainability through circular economy might again cause more localization.

\subsection{Stakeholders}

Following the ecosystem analogy, IS is not just one supply chain, but a web of interdependencies between companies that have their own supply chains, often global. Besides the companies in the IS network, several additional stakeholders may be involved or affected. Since IS is often organized in industrial areas, they involve local employment and create regional job opportunities. In addition, IS affects the local community by its focus on waste reduction and energy efficiency. In Kalundborg, the surrounding municipality is for instance an important stakeholder as it receives part of its residential heating from the network.

Regulatory bodies are also important stakeholders. On the (inter)national level, landfill and energy usage taxes and waste management regulations affect companies. In fact, the EU Directive on Waste (2008/98/EC) mandates member countries to address waste and by-product reuse (Costa and Ferrão, 2010). Similarly, regulatory pressure has been a driver behind IS initiatives in the United States, Australia, and Asia (Chertow and Lombardi, 2005; van Beers et al., 2007; Behera et al., 2012). Governmental frameworks, such as the NISP in the UK, also facilitate information exchange among different ISs and provide feedback loops for policy makers (Mirata, 
2004). Furthermore, regional governments often promote IS initiatives and attract regional investments, as well as provide financial support for their development (Behera et al., 2012). However, restrictive waste treatment laws can also act as barriers to IS initiatives (Mirata, 2004; Schwarz and Steininger, 1997). An example is Kalundborg, where legislation restricts the feeding of local pigs with waste biomass from an enzyme factory. Consequently, the European Commission currently has a focus on adapting regulation to facilitate the exchange of by-products as part of its Action Plan for Circular Economy (EC, 2015).

The role of non-governmental organizations is also important in many IS networks. As can be seen in Table 1, more than half of the networks have an organizational unit, in the form of private organizations, public agencies, NGOs, as well as research institutes. Responsibilities of the organizational unit in Ulsan, for example, are to find potential partners, conduct feasibility studies, and to financially support and monitor commercialization (Behera et al., 2012; Park et al., 2016). In this case, and in many other cases, like in the NISP and in Tianjin, the organizational unit is responsible for establishing collaboration in the industrial area to improve economic and environmental performance (Mirata, 2004; Shi et al., 2010). In Kalundborg and in Kwinana, the organizational units comprise local industries that besides integrating environmental considerations into their profit-related objectives also integrate local community interests (Jacobsen, 2006; van Beers et al., 2007). Additional activities of the organizational units include monitoring operations, facilitating studies of the industrial symbiosis, and disseminating knowledge (nationally and internationally) among other IS initiatives. Research institutes can also be involved in the organizational unit. For example, in Ulsan, the person in charge of driving IS development, bringing businesses together, and stimulating their further participation was an academic researcher (Behera et al., 2012). In other cases, researchers are involved indirectly. For example, researchers from two universities conducted feasibility studies in Rotterdam (Baas, 2011), and researchers introduced the concept of IS to a local government in Portugal, supporting the establishment of a recycling network in the Chamusca region (Costa and Ferrão, 2010). 


\subsection{Expectations, drivers, and sustainability performance}

As depicted in Figure 2, the pressures and incentives of stakeholders on the one hand and the collaborative sustainable supply chain effort on the other hand meet at the triple bottom line of sustainability; consequently, this section is structured around each of the three bottom lines.

\subsubsection{Profit-related sustainability performance}

Ideally, reusing by-products and scrap materials manifests a closed-loop system (French and LaForge, 2006). Companies mostly invest in closed-loop supply networks to gain economic benefits and to improve their environmental profile (Guide and van Wassenhove, 2006). By-products in IS substitute raw materials and are often cheaper than the original raw materials due their negligible "production" costs and close proximity.

For example, in Nanjangud, Southern India, a company extracts oils and moisture from several food-grade and biomass residue streams (such as coffee grounds, coconut, and sawdust), largely from within the IS network, and sells its product to a soap manufacturer (Bain et al., 2010). In Rotterdam, $\mathrm{CO}_{2}$ recovery from heat suppliers made it possible to supply hundreds of greenhouses (Baas, 2011). This created a new market for wasted emissions and substituted $\mathrm{CO}_{2}$ generation by natural gas combustion at the greenhouses. Flue gas treatment in power generation from coal results in by-products like fly ashes and gypsum that can be reused in cement factories and by plasterboard manufacturers, allowing producers in the vicinity of the plants to save significant transportation costs by avoiding delivery from abroad (Schwarz and Steininger, 1997; Jacobsen, 2006). Additionally, thermal power plants generate excess energy in the form of steam and heat, which can be reused in other industrial processes; consequently, their onsite production can be avoided (Chertow and Lombardi, 2005). In Kalundborg, treated organic sludge from a large biotech company partnering in the IS is used as fertilizer, which provides collective benefits. In fact, companies avoid disposal costs by supplying their organic waste to local farms instead of disposing it in a landfill and farmers obtain cheap organic fertilizer on agricultural soils in the region, improving soil properties and saving the application of industrial fertilizers. In some cases, collaborative 
benefits emerge through shared logistical services, including storing processing and transportation (Bain et al., 2010; Geng and Côté, 2002; Mirata, 2004).

Investing in IS is generally an efficiency improvement project with a relatively short expected return of investment (Mirata, 2004; Baas, 2011). However, financial conditions of by-product treatment, storage, and delivery, are one of the first reasons why companies sometimes reject the idea of IS. Furthermore, changing economic conditions may inhibit the expansion of the network or even cause companies to change back to more conventional economic development (Gibbs and Deutz, 2007). Due to the substantial initial costs of IS relationships, companies often rely on financial support from private investors and governmental bodies (e.g. Behera et al., 2012; Shi et al., 2010). Without such support or in case of long payback periods, companies can be reluctant to participate. For example, an IS initiative in Sweden was phased out after the research and external subsidies ended (Mirata and Emtairah, 2005; Baas, 2011).

\subsubsection{Planet-related sustainability performance}

Essentially, activities in the supply chain have the potential to degrade the natural environment by depleting its resources and deteriorating the environmental quality with waste disposal and pollution emission (Gupta, 1995). In general, IS reduces the amount of waste that would otherwise be landfilled or released as emissions to air or water and at the same time it improves companies' resource efficiency by emphasizing material reuse, avoiding the environmental impacts accompanying the extraction or production of virgin resources. Furthermore, utilizing wastewater components and excess heat and steam exchanges in IS contributes to optimal use of energy and water, and is one of the main features of industrial ecosystems (Frosch and Gallopoulos, 1989). Saving energy also indirectly reduces emissions by reducing the need for electricity from power plants. The Kalundborg IS is one of the pioneers of such energy and water cascading (Jacobsen, 2006).

Besides profit, a main driver for companies to engage in IS is often conforming with environmental regulations. For example, in Portugal, a new environmental law on improved waste management triggered the organization of the Chamusca IS (Costa and Ferrão, 2010). Similarly, 
in Puerto Rico, a US regulation specifying that energy providers must also produce output other than electricity initiated steam production at the power plant, serving as a basis for the Guayama IS (Chertow and Lombardi, 2005). In Australia, increased community and governmental pressure to protect the marine environment initiated the establishment of the Kwinana Industries Council, which became the organizational unit for the local IS (van Beers et al., 2007).

However, companies don't always need regulatory incentives to trigger IS. For example, environment-oriented behaviour of companies was observed in Nanjangud, South India, where the recycling of non-hazardous industrial by-products and other wastes has been implemented in the absence of regulatory framework (Bain et al., 2010). On the other hand, IS activities do not always meet the environmental performance expectations, particularly when the involved companies are focused only on their economic interests and the broader environmental implications are overlooked (Ashton, 2011).

Innovation in terms of clean technologies born from symbiotic relationships is rare since companies often focus on the reuse of waste, and not its prevention. Consequently, an important concern about IS is that it perpetuates waste streams instead of preventing them (Duflou et al., 2012). For example, promoting the cogeneration heat and power plant in the Humber region IS could potentially counteract the feasibility of any future renewable energy projects (Mirata, 2004). At the same time, national initiatives ensuring a $\mathrm{CO}_{2}$ neutral energy system in Denmark limit the long-term viability of leveraging excess utilities from the central power plant in the Kalundborg IS.

Although IS is typically based on old production technologies, innovation in products and processes can certainly play a role. For example, in the Handelö IS, biofuel production has been researched and implemented on industrial scale, and it now successfully fuels public transportation vehicles in Norrköping (Martin and Eklund, 2011). Developments in Tianjin resulted in an innovative technology to produce new soil out of three solid wastes: sea sediments, caustic soda sludge, and fly ash from the local power plants. In Kalundborg, small-scale production plants 
have recently started to test and scale up algae farms producing biomass fed on wastewater and to produce biofuel from wheat straw. Furthermore, research and development related to by-product reuse contributed to technical and organizational innovations in the German chemical industry (Sterr and Ott, 2004). Therefore, IS also has the potential to be a driver of innovation for regional sustainability (Baas, 2011). However, innovation in IS is rather architectural than radical (Henderson and Clark, 1990): it combines existing parts in new ways, for example creating new building materials from waste.

\subsubsection{People-related sustainability performance}

The people affected by operations include employees, consumers, as well as the population living in proximity of supply chain operations (Tang and Zhou, 2012). In fact, industrial parks employ people on a large scale, and their contribution to the local community's development can be significant. Accordingly, many IS initiatives were primarily driven by job creation opportunities (Gibbs and Deutz, 2007). For example, the medium-sized Kalundborg IS provides jobs to more than four thousand employees, a considerable share of which would not be employed without the IS activities; and the relatively small-scale Valuepark Schkopau in Germany already created seven hundred jobs (Liwarska-Bizukojc et al., 2009). A new production unit to utilize excess steam in Ulsan, South Korea, resulted in more than a hundred new jobs (Behera et al., 2012).

Companies in IS have also been known to promote personal development and well-being of their employees. The organizational unit of the Ulsan IS organizes training sessions to educate people and guide companies in creating a better work environment (Behera et al., 2012). Additionally, for active public promotion and encouraging public participation in Ulsan, successful IS cases are advertised through electronic media and newspaper.

By reducing the companies' environmental impact, IS also enhances the local community's image with cleaner landscapes, air and water. IS may also incorporate waste streams (e.g. solid waste and wastewater) from the local municipality, and excess heat can be supplied to the local community (Saikku, 2006; Jacobsen, 2006; Baas, 2011). As a result of available jobs, a healthy 
environment, and economic potential, IS has the potential to attract people to municipalities, which might otherwise face decreasing population, thereby contributing to regional development.

IS not only emphasizes social responsibility by employment, but also by maintaining close social relationships within the supply networks (Schwarz and Steininger, 1997). Social networking is often used to create a balanced business environment and enhance collaboration (Lamming et al., 2000). Trust, open communication, and joint problem solving are essential for the functioning of the IS, and are leveraged through social networking (Baas, 2011). Thereby, companies in IS emphasize transparency and disseminate information among business partners. According to Carter and Rogers (2008), transparency also works the other way around, by actively engaging stakeholders to secure their commitment and improve supply chain processes. As transparency should also reduce unethical (or illegal) behaviour, social sustainability is further improved, while at the same time the transaction costs for external stakeholders interested in assessing a company's social responsibility is reduced (Carter and Rogers, 2008).

\section{Supply network collaboration in industrial symbiosis}

Figure 1 summarized the organizational and operational aspects of the collaborative efforts between companies in IS networks that facilitate sustainability performance. This section gives an overview of collaboration challenges, discussing first the organizational inter-dependencies and the role of the organization and secondly the operational aspects of IS developments. Based on this, the collaborative supply chain perspective from Section 2 is extended into propositions reflecting the main requirements related to the organizational and operational aspects in the context of IS networks (listed in Figure 1).

\subsection{Organizational challenges in industrial symbiosis}

IS networks can create a context for collective problem definition and an interface to develop solutions in a collaborative manner (Mirata and Emtairah, 2005), and an organizational unit can 
facilitate these processes. IS examples show the importance of centrally organized local meetings (e.g. business match-making) where companies have opportunity to meet each other, attract new companies and establish personal relationships (e.g. Costa and Ferrão, 2010; Behera et al., 2012). At these meetings, regional problems, stakeholder expectations, and development plans are discussed (e.g. Mirata, 2004; Costa and Ferrão, 2010; Baas, 2011). The organizational unit also provides a shortcut between the companies and the local authorities and may be used to provide information about environmentally sustainable actions (Mirata, 2004). Such communication channels allow presentation of ideas, exchange of project experiences, and learning about stakeholder expectations (Costa and Ferrão, 2010). Knowledge and experience sharing emphasizes collective learning of companies, enhancing their collective capacity to identify new perspectives for development (Simatupang et al., 2002). Collective learning in IS facilitates the understanding of region-specific capabilities and cultural change associated with sustainability (Gibbs and Deutz, 2007). The resulting region-specific knowledge allows companies to identify common problems and jointly work out mutually beneficial solutions. Identifying incentives can lead to collaborative projects for sustainability improvements where companies share interests. For example, in Kalundborg, groundwater deficits have been a societal problem for decades. As a result of collaboration, a number of private and public projects has been initiated including symbiosis between water-consuming industries (Jacobsen, 2006). Collective learning may also enhance the innovation capability of companies (Bansal and McKnight, 2009); thus, collective learning in IS may increase the regional competitiveness in a sustainable way. For example, in Tianjin, to prevent further farmland degradation companies developed an innovative technology to produce new soil from a combination of sea sediment, caustic soda sludge and fly ash (Shi et al., 2010). Especially for SMEs, such external inputs are often a necessary (but not sufficient) condition for development of environmental capabilities (Lee and Klassen, 2008).

Although a central organization may play an important role in IS, the supply network is also self-organized by the participating companies (Lowe, 1997). Coordination in the IS network en- 
sures long-term sustainability with strategic alignment. Incentive alignment between companies is facilitated by mutually shared interests for economic gains and reduced environmental impact. The long-term commitment also depends on the equivalent sharing of risks and benefits (Behera et al., 2012). However, incentive alignment is difficult when companies are forced into contracts without knowing the potential risks and benefits of participating in IS. In the Humber region IS in the UK, for example, only around 20 out of 150 contacted companies showed interests in the program due to the lack of trust and information (Mirata, 2004). Furthermore, interdependencies in IS are sometimes asymmetric, meaning that one party has more power than the other(s). In fact, IS often settles around "powerful" companies, for example power plants, water supply/treatment facilities and chemical producers, which are able to provide a large amount of by-products, excess utilities, or services (Jacobsen, 2006; Liwarska-Bizukojc et al., 2009). These so-called anchor organizations can create a critical mass for IS development, but their market exit is also a potential risk for the IS (Chertow, 2000). Furthermore, the evolution of IS networks might change the nature of collaboration (Chertow and Ehrenfeld, 2012; Baas, 2011), including an increased focus on IS as a solution for waste management and production efficiency.

Losing a by-product supplier or buyer, for example due to relocation, or due to a change in the by-product characteristics, can endanger the integrity of the network (Lowe, 1997; Bansal and McKnight, 2009). By-product supply (and demand) is subject to the primary production activities, therefore, risk mitigation might involve multiple buyers (suppliers). On the one hand, this might introduce redundancy to the network; on the other hand, it increases resilience in case of facing shortages or partner drop outs. Furthermore, by-product exchanges can create a technological lock between the companies. Building a symbiotic exchange on technologies that may become obsolete in the future undermines the sustainability of IS. Furthermore, IS is exposed to changes in the contemporary regulatory framework. However, building a broader by-product exchange is one the roles of central organizations (Lowe, 1997). Central coordination needs to be strategic about IS, the environmental issues it may perpetuate, and the future expansion of the IS network. 
It is however important to note that not all wastes are hazardous, and that waste is unlikely to be entirely eliminated through cleaner production and pollution prevention (Erkman, 1997; Lowe, 1997). Therefore, IS can be a long-term, feasible option for companies that generate nonhazardous wastes if the waste streams are sustained. Nevertheless, if companies don't see or lose economic incentives in the by-product exchange, they will not participate or exit the IS. Consequently, the main organizational challenge concerning the sustainability of IS is to integrate sustainable technologies, which can run without undermining their own basis.

A further challenge is to sustain the economic incentives between the participants as well as to win their trust in the collaboration. Governmental regulations and central organization on regional level can facilitate these initiatives. Indeed, trust and consistent information are important enablers of strategic alliance in collaborative supply networks (Hoyt and Huq, 2000). In IS, trust among the broad set of stakeholders (e.g. industries, governments, environmental and local interest groups) is an enabler of knowledge and information sharing and is essential for long-term business relationships (Baas, 2011). Trust between companies is determined by pre-existing links but can also be developed through social networking.

In conclusion, several propositions on the organizational aspects of supply chain collaboration in IS networks can be identified. First, related to the supply chain integration practices, we conclude the following:

Proposition (1a) Collaborative strategic project definitions in IS networks require the development towards non-hazardous by-product synergies between environmentally sustainable processes.

Proposition (1b) Knowledge transfer and integration in IS networks requires the establishment of a communication platform that connects local producers (or industries) with regulatory bodies, environmental experts, and community advocates.

Secondly, related to the supply chain coordination practices, we conclude the following:

Proposition (2a) Incentive alignment in IS networks requires the creation of a framework for shar- 
ing the costs, risks, and benefits of by-product synergies and emphasizing local economic, environmental, and social problems.

Proposition (2b) Collective learning in IS networks requires the engagement of producers (industries) in learning about each others needs in order to guide them towards collaboration in solving strategic problems.

\subsection{Operational challenges in industrial symbiosis}

Operational aspects of IS comprehend the management of material exchanges. The spectrum of material exchanges in IS spans from simple dyadic (supplier-buyer) relationships to networks involving several buyers and suppliers. An IS typically involves multiple of such interdependencies. Additionally, companies in IS may complement incoming by-product streams with original raw materials. Dyadic relationships between two plants in IS may evolve to reciprocal by-product exchanges; for example, in Nanjangud, a beverage producer provides coffee grounds to an oil processor, who in turn provides biomass fuel to the beverage producer (and other companies) (Bain et al., 2010).

In IS, a supplier can be a sole provider of industrial waste for several buyers. Cogeneration power and heat plants typically supply excess steam and heat to more than one buyer due to the fact that this form of excess energy is useful in many industries (Jacobsen, 2006). Similarly, one can receive industrial wastes from more than one plant. For example, in Ulsan, a company receives and processes zinc waste from three plants inside the IS and provides the resulting product to a paint producer (Behera et al., 2012). Relationships within IS can connect more levels of actors leading to a chain of suppliers and buyers, and companies can participate in more material exchanges at the same time. For example, in Nova Scotia, industrial waste collectors recover by-products such as paints, oils, and scrap materials (Geng and Côté, 2002). Nevertheless, ongoing production is not always necessary to have a feedstock of by-products. For example, in Kwinana, a stockpile of gypsum waste from the 1980s is now utilized by plasterboard manufacturers and local farmers 
(van Beers et al., 2007).

By-products and scrap materials are frequent output of process industries, such as chemical, oil, steel, forestry, agricultural, and food industries (Fransoo and Rutten, 1994). Due to the divergent production processes, many products are produced from a few raw materials, and production often yields unwanted but also un-avoidable by-products. Based on the available case studies, it is clear that IS mainly involves process industries and often involves water and energy treatment and supply. Sometimes, IS also incorporates other waste streams like electronic waste, end-of-life vehicle handling, or municipal solid waste treatment (e.g. Geng and Côté, 2002; Costa and Ferrão, 2010; Bain et al., 2010).

The feasibility of IS is affected by its geographical range (Sterr and Ott, 2004; Gibbs and Deutz, 2007). Intuitively, by increasing the geographical range, the number of potential partners is higher and total supply and demand of by-products (and excess utilities) also grows. Furthermore, by involving more companies in the by-product exchange, the economic viability improves and the system becomes more resistant to fluctuations or failures (Lowe, 1997; Sterr and Ott, 2004). However, increasing the distance inherently decreases the cost effectiveness of the by-product exchange and adds to the environmental impact due to the increased effort in transportation. It also becomes increasingly difficult to agree on by-product exchanges at longer distances since businesses are more likely to be less familiar with each other's activities. Moreover, in case of perishable materials, a long distance is explicitly infeasible. In short, there is a trade-off between the geographical range and the efficiency of an IS.

Operational considerations in IS relate to the management of production, transportation, and use of industrial waste, as well as the synchronization of these logistical activities between supplier and buyer on a tactical level. Before usage, exchanged materials often need to go through additional treatment processes, storage, and transportation (Duflou et al., 2012). The treatment of by-products may require individual value adding processes such as mixing, separating, forming, or chemical reactions (Flapper et al., 2002). The resulting bulk materials can be transported by 
trucks. In some ISs, a joint distribution service is used to reduce the logistical effort (e.g. Geng and Côté, 2002). Furthermore, utility exchanges (e.g. steam and water) usually involve pressure conservation and settling and require a pipeline network for delivery (Jacobsen, 2006). On the other end of the supply chain, being able to use a by-product possibly involves process adjustments because it might differ from the previously used original raw materials (Duflou et al., 2012).

Natural variations in product quality lead to variability in by-product quantity (through different yields) and quality (Fransoo and Rutten, 1994). Depending on the requirements of the buyer, such quality variations can inhibit symbiotic relationships (Bansal and McKnight, 2009). Furthermore, the availability of industrial waste is the result of a push process, meaning that surplus or shortage can occur due to the variability in supply and demand, and the different seasonal characteristics in different industries. In order to deal with surplus and shortage in IS, industrial waste may need to be stored, excess waste might have to be disposed, additional original raw materials may need to be purchased, or limited waste quantities might have to be divided over multiple interested buyers. From the cases, it seems that a significant part of the exchanged by-products in IS are durable, meaning that inventories can be stored. Nevertheless, holding by-product inventory requires additional space and incurs costs. Other by-products like waste oils and biomass are perishable. Moreover, the exchange of utilities, such as steam and heat, implies very strict perishability.

Generally speaking, by-products are different from original materials, and consequently, operating with by-products increases the effort in designing and operating storage facilities and production systems. Also, alternating between by-products and original raw materials or combining them complicates the production. This includes both technical aspects such as storage space and equipment connectivity, as well as operational aspects such as inventory management, purchasing of raw materials, and planning of production with multiple material sources. Furthermore, the sourcing of by-products and original raw materials simultaneously might affect agreements with original raw material suppliers, potentially leading to higher costs. Also, supply chain agreements 
coordinating partnerships need to be flexible in order to cope with the higher uncertainty of byproduct supply, and need to be able to cover a multiple supplier-buyer network to ensure a certain resilience.

Aggregate and temporal logistical information concerning waste streams is important in evaluating potential by-product exchanges. Therefore, a central information system, where companies can share information about their waste streams and learn about other companies, can be used in the development phase of IS (Sterr and Ott, 2004; Grant et al., 2010; Dhanorkar et al., 2015). Such an information systems have for instance been developed to facilitate IS in the case of NISP, in Kwinana, and in the US (Cimren et al., 2011; Paquin and Howard-Grenville, 2012; van Beers et al., 2007), and matching algorithms have also recently been developed to support the establishment of exchanges (Cecelja et al., 2015). It can however be challenging to obtain the necessary information from companies, especially when they have uncertainties in their primary production activities. However, flexible contracts between partners can manage the uncertainties and fluctuations around by-product supply and demand. The assessment of material flows (e.g. quantity, quality, distribution over time) can be used to optimize the network design and material flows in terms of costs and environmental impacts. For example, the implementation of the Kansas City IS was supported by an optimization model that evaluated the different configurations of potential participants (Cimren et al., 2011). However, temporal dynamics of supply and demand of by-products have so far not been captured by information systems or by production and inventory management (Grant et al., 2010; Cimren et al., 2011). Nevertheless, a resulting logistical synchronization capability would have positive impact on the supply network's operational efficiency.

In conclusion, several propositions on the operational aspects of supply chain collaboration in IS networks can be identified. First, related to the supply chain integration practices, we conclude the following:

Proposition (3a) Production and delivery systems in IS networks require (i) the implementation of a local by-product collection and delivery system, and (ii) the integration of by-product treatment, 
storage, and reuse into regular operations.

Proposition (3b) Information systems for operational data in IS networks require the sharing of aggregated and temporal information on by-product flows with a network of current and potential partners.

Secondly, related to the supply chain coordination practices, we conclude the following:

Proposition (4a) Supply-demand agreements in IS networks require the development of agreements that facilitate redundancy in, and hence resilience of, the supply and demand of by-products in the IS network.

Proposition (4b) Logistical synchronization in IS networks requires the management of variability in quality and quantity of by-product flows as well as the matching of supply and demand.

\section{Conclusion and perspectives}

To improve the environmental sustainability of operations management, recent research suggested building bridges between operations management and industrial ecology. Industrial symbiosis (IS), as a concrete implementation of industrial ecology, pursues industrial ecosystem thinking in which companies from different industries form a supply network collaboration based on the local recycling of industrial waste, by-products, and excess utilities. Previous literature finds that IS networks support regional sustainable development by improving the companies' resource efficiency and competitiveness, creating new employment, and by contributing to a cleaner natural environment. Companies in IS networks show significant effort in achieving competitive advantage in a collectively beneficial way by emphasizing cooperation. In this paper, we contribute to this development by providing a detailed supply chain collaboration perspective on the organization and operation of IS networks, including the development of propositions on the main requirements for supply chain integration and coordination. 
From an organizational perspective, we show that IS emphasizes transparency, shared cultural norms, social networking, and trust, which all allow companies to understand each other's capabilities and to form strategic alliances based on economic drivers as well as social and environmental responsibility. The existence of central organizational units distinguishes IS from other supply network collaborations. The organizational unit contributes to the development of IS networks by functioning as a central hub that augments communication between stakeholders, facilitates business match-making, and helps region-specific collective learning. As such, it helps address some of the organizational challenges identified in this paper. IS also implies risks for participants due to high levels of interdependency in supplier-buyer relationships; consequently, companies have concerns regarding such long-term collaboration. Nevertheless, in many of the analyzed cases, IS demonstrated resilience over several decades. Moreover, examples show that companies in IS networks, driven by profitability and resource scarcity as well as pressure of governmental regulations, are able to deliver innovative solutions in terms of non-hazardous waste utilization. Yet, focusing on and integrating sustainable technologies in strategic project definitions and engaging companies in long-term partnerships are great challenges for IS.

From an operational perspective, IS engages companies in the collection, treatment, and storage of by-products and delivering them to other producers. Previous research, which often modelled by-product exchanges on an aggregate level, points to trade-offs between the geographical distance between supplier and buyer and the related resource efficiency of IS. However, temporal dynamics in industrial symbiosis have not been addressed. One key question is how to manage a lack of synchronicity between by-product supply and demand, originating at different production facilities with potentially different seasonal characteristics and short-term variability. This implies inventory management challenges, which could be addressed by synchronizing by-product exchanges between multiple suppliers and buyers. This would reduce by-product quantity uncertainties and increase the feasibility of long-term supply and demand agreements. Furthermore, dealing with quality variations of by-products and integration with other raw material sources can 
lead to procurement and production management challenges. These problems might be addressed with flexible contracts, further by-product treatment (e.g. separation and mixing), and by alternating between or combining by-products and original raw materials. Consequently, there are ample opportunities for further research regarding by-product inventory management and production planning combining different by-products with original materials.

Even though financial considerations remain the driving factor of companies within IS, increasingly scarce natural resources and increasing regulation on waste and emissions cause companies to more and more consider the environmental and social implications of their operations. In the EU, the European Commission's Action Plan for Circular Economy identifies IS as a central strategy to increase resource efficiency in order to promote European environmental sustainability and reduce the dependency of European industries on external raw material supplies. Clearly, in order to be successful, IS needs specific circumstances, which involve facilitating regulatory frameworks, and require long-term industry commitment. However, in light of new economic, environmental, and social challenges, the local industrial waste recycling leveraged in IS networks might be a viable route towards the sustainability of production operations if the underlying technologies are selected carefully, and the European action plan suggests a number of initiatives to improve the conditions for IS. Our overview of the key organizational and operational requirements for successful collaboration in IS networks (summarized in our propositions) supports a much needed improved understanding of the collaborative supply network dimension of IS networks, helping assess the economic, environmental, and social performance of current and future IS initiatives, as well as providing a basis for hypothesis development in further research related to our propositions.

\section{References}

Arshinder, K. A., Deshmukh, S. G., 2008. Supply chain coordination: Perspectives, empirical studies and research directions. International Journal of Production Economics 115 (2), 316-335. 
Ashton, W., 2011. Managing performance expectations of industrial symbiosis. Business Strategy and the Environment 20 (5), 297-309.

Baas, L., 2011. Planning and uncovering industrial symbiosis: comparing the Rotterdam and östergötland regions. Business Strategy and the Environment 20 (7), 428-440.

Baas, L. W., Boons, F. A., 2004. An industrial ecology project in practice: exploring the boundaries of decisionmaking levels in regional industrial systems. Journal of Cleaner Production 12 (8-10), 1073-1085.

Bain, A., Shenoy, M., Ashton, W., Chertow, M., 2010. Industrial symbiosis and waste recovery in an indian industrial area. Resources, Conservation and Recycling 54 (12), 1278-1287.

Bansal, P., McKnight, B., 2009. Looking forward, pushing back and peering sideways: Analyzing the sustainability of industrial symbiosis. Journal of Supply Chain Management 45 (4), 26-37.

Behera, S. K., Kim, J.-H., Lee, S.-Y., Suh, S., Park, H.-S., 2012. Evolution of 'designed' industrial symbiosis networks in the Ulsan Eco-industrial Park: 'research and development into business' as the enabling framework. Journal of Cleaner Production 29-30, 103-112.

Boons, F. A., Janssen, M., 2004. The myth of kalundborg: Social dilemmas in stimulating eco-industrial parks. In: van den Bergh, J., Janssen, M. (Eds.), Economics of industrial ecology. MIT Press, Cambridge, MA, pp. 337-355.

Carter, C. R., Rogers, D. S., 2008. A framework of sustainable supply chain management: Moving toward new theory. International Journal of Physical Distribution \& Logistics Management 38 (5), 360-387.

Cecelja, F., Trokanas, N., Raafat, T., Yu, M., 2015. Semantic algorithm for industrial symbiosis network synthesis. Computers \& Chemical Engineering 83, 248-266.

Chertow, M., Ehrenfeld, J., 2012. Organizing Self-Organizing Systems. Journal of Industrial Ecology 16 (1), 13-27.

Chertow, M. R., 2000. Industrial symbiosis: Literature and taxonomy. Annual Review of Energy and the Environment 25 (1), 313-337.

Chertow, M. R., 2007. "Uncovering” industrial symbiosis. Journal of Industrial Ecology 11 (1), 11-30.

Chertow, M. R., Lombardi, D. R., 2005. Quantifying economic and environmental benefits of co-located firms. Environmental Science and Technology 39 (17), 6535-6541.

Cimren, E., Fiskel, J., Posner, M.E., Sikdar K., 2011. Material flow optimization in by-product synergy networks. Journal of Industrial Ecology 15 (2), 315-322.

Costa, I., Ferrão, P., 2010. A case study of industrial symbiosis development using a middle-out approach. Journal of Cleaner Production 18 (10-11), 984-992.

de Leeuw, S., Fransoo, J., 2009. Drivers of close supply chain collaboration: One size fits all? International Journal of Operations \& Production Management 29 (7), 720-739.

Dhanorkar, S., Donohue, K., Linderman, K., 2015. Repurposing materials and waste through online exchanges: Overcoming the last hurdle. Production and Operations Management 24 (9), 1473-1493.

Diabat, A., Govindan, K., 2011. An analysis of the drivers affecting the implementation of green supply chain management. Resources, Conservation and Recycling 55, 659-667.

Duflou, J. R., Sutherland, J. W., Dornfeld, D., Herrmann, C., Jeswiet, J., Kara, S., Hauschild, M., Kellens, K., 2012. Towards energy and resource efficient manufacturing: A processes and systems approach. CIRP Annals Manufacturing Technology 61 (2), 587-609.

EC, 2015. Closing the loop - An EU action plan for the circular economy. In: Communication from the Commission to the European Parliament, the Council, the European Economic and Social Committee and the Committee of the Regions. European Commission, Brussels, cOM(2015), 614/2.

Erkman, S., 1997. Industrial ecology: an historical review. Journal of Cleaner Production 5 (1-2), 1-10.

Flapper, S. D. P., Fransoo, J. C., Broekmeulen, R. A. C. M., Inderfurth, K., 2002. Planning and control of rework in the process industries: A review. Production Planning \& Control 13 (1), 26-34.

Fransoo, J. C., Rutten, W. G., 1994. A typology of production control situations in process industries. International Journal of Operations \& Production Management 14 (12), 47-57.

French, M. L., LaForge, R. L., 2006. Closed-loop supply chains in process industries: An empirical study of producer re-use issues. Journal of Operations Management 24 (3), 271-286.

Frohlich, M. T., Westbrook, R., 2001. Arcs of integration: an international study of supply chain strategies. Journal of Management 19, 185-200.

Frosch, R. A., Gallopoulos, N. E., 1989. Strategies for manufacturing. Scientific American 261 (3), $144-152$. 
Geng, Y., Côté, R. P., 2002. Scavengers and decomposers in an eco-industrial park. International Journal of Sustainable Development \& World Ecology 9 (4), 333-340.

Gibbs, D., Deutz, P., 2007. Reflections on implementing industrial ecology through eco-industrial park development. Journal of Cleaner Production 15 (17), 1683-1695.

Grant, G. B., Seager, T. P., Massard, G., Nies, L., 2010. Information and communication technology for industrial symbiosis. Journal of Industrial Ecology 14 (5), 740-753.

Guide, V. D. R., van Wassenhove, L. N., 2006. Closed-loop supply chains: An introduction to the feature issue (part 2). Journal of Operations Management 15 (4), 471-472.

Gupta, M. C., 1995. Environmental management and its impact on the operations function. International Journal of Operations \& Production Management 15 (8), 34-51.

Hauschild, M. Z., 2015. Better - But is it Good Enough? On the Need to Consider Both Eco-efficiency and Ecoeffectiveness to Gauge Industrial Sustainability. Procedia CIRP 29, 1-7.

Henderson, R. M., Clark, K. B., 1990. Architectural innovation: The reconfiguration of existing product technologies and the failure of established firms. Administrative Science Quarterly 35 (1), 9-30.

Henriques, I., Sadorsky, P., 1999. The relationship between environmental commitment and managerial perceptions of stakeholder importance. Academy of Management Journal 42 (1), 87-99.

Hoyt, J., Huq, F., 2000. From arms-length to collaborative relationships in the supply chain. International Journal of Physical Distribution \& Logistics Management 30 (9), 750-764.

Inkpen, A. C., Tsang, E., 2005. Social capital, networks, and knowledge transfer. Academy of Management Review 30 (1), 146-165.

Jacobsen, N. B., 2006. Industrial symbiosis in Kalundborg Denmark: A quantitative assessment of economic and environmental aspects. Journal of Industrial Ecology 10 (1-2), 239-255.

Jagdev, H. S., Thoben, K.-D., 2001. Anatomy of enterprise collaborations. Production Planning \& Control 12 (5), 437-451.

Kleindorfer, P. R., Singhal, K., van Wassenhove, L. N., 2005. Sustainable operations management. Production and Operations Management 14 (4), 482-492.

Kumar, K., van Dissel, H. G., 1996. Sustainable collaboration: Managing conflict and cooperation in interorganizational systems. MIS Quarterly 20 (3), 279.

Lamming, R., Johnsen, T., Zheng, J., Harland, C., 2000. An initial classification of supply networks. International Journal of Operations \& Production Management 20 (6), 675-691.

Lee, S.-Y., Klassen, R. D., 2008. Drivers and enablers that foster environmental management capabilities in smalland medium-sized suppliers in supply chains. Production and Operations Management 17 (6), 573-586.

Linton, J., Klassen, R., Jayaraman, V., 2007. Sustainable supply chains: An introduction. Journal of Operations Management 25 (6), 1075-1082.

Liwarska-Bizukojc, E., Bizukojc, M., Marcinkowski, A., Doniec, A., 2009. The conceptual model of an eco-industrial park based upon ecological relationships. Journal of Cleaner Production 17 (8), 732-741.

Lowe, E. A., 1997. Creating by-product resource exchanges: Strategies for eco-industrial parks. Journal of Cleaner Production 5 (1-2), 57-65.

Martin, M., Eklund, M., 2011. Improving the environmental performance of biofuels with industrial symbiosis. Biomass and Bioenergy 35 (5), 1747-1755.

Massard, G., Jacquat, O., Wagner, L., Zürcher, D., 2012. International survey on eco-innovation parks: Learning's from experiences on the spatial dimension of eco-innovation.

Meixell, M. J., Luoma, P., 2016. Stakeholder pressure in sustainable supply chain management. International Journal of Physical Distribution \& Logistics Management 45 (1-2), 69-89.

Miemczyk, J., Johnsen, T., Macquet, M., 2012. Sustainable purchasing and supply management: a structured literature review of definitions and measures at the dyad, chain and network levels. Supply Chain Management: An International Journal 17 (5), 478-496.

Mirata, M., 2004. Experiences from early stages of a national industrial symbiosis programme in the UK: determinants and coordination challenges. Journal of Cleaner Production 12 (8-10), 967-983.

Mirata, M., Emtairah, T., 2005. Industrial symbiosis networks and the contribution to environmental innovation. Journal of Cleaner Production 13 (10-11), 993-1002. 
Paquin, R. L., Howard-Grenville, J., 2012. The evolution of facilitated industrial symbiosis. Journal of Industrial Ecology 16 (1), 83-93.

Park, J. M., Park, J. Y., Park, H.-S., 2016. A review of the National Eco-Industrial Park Development Program in Korea: progress and achievements in the first phase, 2005-2010. Journal of Cleaner Production 114, 33-44.

Saikku, L., 2006. Eco-industrial parks: A background report for the eco-industrial park project at Rantasalmi.

Schwarz, E. J., Steininger, K. W., 1997. Implementing nature's lesson: The industrial recycling network enhancing regional development. Journal of Cleaner Production 5 (1-2), 47-56.

Seuring, S., Müller, M., 2008. From a literature review to a conceptual framework for sustainable supply chain management. Journal of Cleaner Production 16 (15), 1699-1710.

Shi, H., Chertow, M., Song, Y., 2010. Developing country experience with eco-industrial parks: a case study of the tianjin economic-technological development area in china. Journal of Cleaner Production 18 (3), 191-199.

Simatupang, T. M., Wright, A. C., Sridharan, R., 2002. The knowledge of coordination for supply chain integration. Business Process Management Journal 8 (3), 289-308.

Spekman, R., Davis, E. W., 2016. The extended enterprise: A decade later. International Journal of Physical Distribution \& Logistics Management 46 (1), 43-61.

Sterr, T., Ott, T., 2004. The industrial region as a promising unit for eco-industrial development—reflections, practical experience and establishment of innovative instruments to support industrial ecology. Journal of Cleaner Production 12 (8-10), 947-965.

Tang, C. S., Zhou, S., 2012. Research advances in environmentally and socially sustainable operations. European Journal of Operational Research 223 (3), 585-594.

Vachon, S., Klassen, R. D., 2007. Supply chain management and environmental technologies: the role of integration. International Journal of Production Research 45 (2), 401-423.

van Beers, D., Corder, C., Bossilkov, A., van Berkel, R., 2007. Regional synergies in the Australian minerals industry: Case-studies and enabling tools. Journal of Industrial Ecology 45 (2), 401-423. 


\section{Highlights}

- Supply chain collaboration perspective on industrial symbiosis (IS) networks

- Development of a theoretical framework to improve understanding of IS performance

- Analysis of IS as a practice of sustainable operations management

- Identification of operational and organizational collaboration challenges

- Research directions for operations and supply chain management research on IS 